Article

\title{
Spatial Price Transmission and Price Dynamics of Global Butter Export Market under Economic Shocks
}

\author{
Huidan Xue ${ }^{1, *}$, Chenguang $\mathrm{Li}^{2}$, Liming Wang ${ }^{1,3}$ and Wen-Hao Su ${ }^{4}(\mathbb{C}$ \\ 1 School of Economics and Management, Beijing University of Technology, Beijing 100124, China; \\ liming.wang@ucd.ie \\ 2 School of Agriculture and Food Science, University College Dublin, National University of Ireland, Belfield, \\ D04 V1W8 Dublin, Ireland; chenguang.li@ucd.ie \\ 3 Irish Institute for Chinese Studies, University College Dublin, D04 V18 Dublin, Ireland \\ 4 College of Engineering, China Agricultural University, Beijing 100083, China; wenhao.su@pku-iaas.edu.cn \\ * Correspondence: xuehuidanll@163.com
}

Citation: Xue, H.; Li, C.; Wang, L.; Su, W.-H. Spatial Price Transmission and Price Dynamics of Global Butter Export Market under Economic Shocks. Sustainability 2021, 13, 9297. https://doi.org/10.3390/su13169297

Academic Editor: Andrea Appolloni

Received: 25 June 2021

Accepted: 10 August 2021

Published: 19 August 2021

Publisher's Note: MDPI stays neutral with regard to jurisdictional claims in published maps and institutional affiliations.

Copyright: () 2021 by the authors. Licensee MDPI, Basel, Switzerland. This article is an open access article distributed under the terms and conditions of the Creative Commons Attribution (CC BY) license (https:// creativecommons.org/licenses/by/ $4.0 /)$.

\begin{abstract}
Recently, the world has experienced striking economic and policy changes, and subsequent uncertainties have impacts on dairy trade price fluctuations. The Global Vector Autoregressive (GVAR) methodology was established in this paper to better understand international butter export prices transmission, the feedback between the economic context changes and price fluctuations, and the link between the global butter market, energy market, and other commodity markets. We assessed which key factors are typically associated with butter export price movements with regards to shocks to crude oil price, palm oil price, farm-gate raw milk price, exchange rates, and consumer price index (CPI) for food of the EU, New Zealand, the U.S., and the rest of world (RoW), respectively. Using generalized impulse response functions, this study found that decreases in farm-gate raw milk price could be swiftly transmitted to butter export prices of not only a home country but other foreign countries. However, palm oil price and crude oil price merely affects global butter export prices. We also found that U.S. dollar depreciations against the Euro will cause a decline in U.S. butter export price. It is concluded that butter export markets are not well-integrated, yet butter export prices of New Zealand and the U.S. are highly linked.
\end{abstract}

Keywords: GVAR; Global Vector Error Correction Model; generalized impulse response functions; spatial price transmission

\section{Introduction}

Recently, the global economy has experienced profound market and policy changes, such as global supply chain disruption, rising economic policy uncertainties, macroeconomic monetary, and fiscal policies changes, as well as global commodity price fluctuations [1-3]. The unprecedented policies and containment measures undertaken by most economies to combat the deadly COVID-19 disease and the increasing protective international food trade restrictions are unavoidably leading to risks of global economic downturn or recession, further disruption in global food supply chain, and economic uncertainties. As an indispensable part of the global value chain, the global dairy trade would be affected from both the demand side and supply side, thus triggering price fluctuations and corresponding welfare loss among stakeholders from producers and processors to retailers, exporters, and then to consumers around the world. Price fluctuations to some extent are inevitable in all types of markets in that they signal changing preferences from the demand side and changing cost and competitive positions from the supply side. The pattern of spatial price transmission among geographically separated countries and the price interaction with inputs, upstream materials prices, macroeconomic indices, and energy prices may offer useful information about market integration (globalization) or segmentation 
(regionalization or localization) as well as offer wise solutions for monitoring and stabilizing export prices $[4,5]$. According to FAOSTAT, the annual values of global dairy and butter trade are 161.35 billion U.S. dollars and 16.22 billion U.S. dollars in 2019, respectively, and their shares of the world GDP are $0.184 \%$ and $0.0185 \%$, respectively. Although this does not seem significant to world GDP, the dairy industry still matters greatly to farmers' livelihood and human's nutrition. The EU and the U.S. are two economies that use tools to solve butter prices fluctuations. In the EU, the dairy sector is subject to the Common Agricultural Policy (CAP), which includes various instruments and market support programmes, such as stockholding interventions and intervention prices for butter aimed to stabilize price if global price decreases. Intervention is used to stabilize the market by purchasing surplus supplies, which are then stored. Intervention stocks are then sold through public tenders when market prices increase. The shocks raised from global economy might cause volatility to butter and other dairy products and affect producers and consumers' welfare as well as the effectiveness of market adjustment and policy. In the early stage of COVID-19 pandemic, dairy industries were heavily affected through multiple mechanisms, such as decreased farmgate milk prices, disruption and difficulties of moving milk within the supply chains, worker shortages, increased production costs, and lack of operating capital [6].The milk was even poured out by dairy farmers due to demand downturn. Therefore, understanding key factors affecting global dairy export prices and spatial price transmission in world dairy exporters is necessary to formulate policies to support the global dairy sector.

Although extensive studies have been done on price transmission in the dairy sector, comprehensive analyses on both spatial and vertical price transmission of export-oriented dairy sector and evaluation of factors affecting dairy prices and market integration still remain unexplored and are important for policy makers, for stakeholders involved in international dairy trade supply chains, and for scholars. Several factors have been proposed in previous literature that influence agricultural commodity prices and might also influence dairy prices, including rising energy prices affecting costs of production inputs and distribution [7-10], U.S. dollar devaluation, and exchange rate fluctuations [11] and so on.

The international dairy market is dynamic and complex, and the prices in geographically separated countries will interact with and be affected by both country-specific and external shocks as well as by global factors. To better understand the global dairy market and its price mechanisms, the Global Vector Autoregressive (GVAR) model proposed by Pesaran et al. [12] was applied to study the spatial price transmission of butter export prices and the links between each of the key factors. Compared with traditional econometric models, such as dynamic equilibrium models and basic Vector Autoregressive model, the GVAR approach has special advantages: (1) the data requirements are relatively low, while at the same time, this high-dimensional model can arrive at rich conclusions via model estimates; (2) it can illustrate the dynamic relationships among studied variables across both country and time spans; (3) it connects country-specific models via several channels of international linkages, deciphering the size and speed of price transmission and shocks from other countries and its domestic markets; and (4) it fits well the objectives of this study: it allows for a high-dimension dataset that allows this study to simultaneously incorporate higher country-dimension, time-dimension, and variable-dimension dataset to conduct dynamic analysis the price transmission and interactions between different countries following market shocks [13].

In this study, butter (butter in the trade market studied in this paper is categorised according to Harmonized System Chapter 4 (HS-4): HS0405-Butter and other fats and oils derived from milk; dairy spreads.) is chosen from various dairy products for the following reasons: (a) the vital export position of butter in the world: butter has remained the fourth largest internationally traded dairy commodity (after whole milk powder, cheese, and skim milk powder) in recent years, in terms of trade weight. It is a vital commodity that is sustained and regulated by stocks and interventional price policies in major dairy exporters, such as the EU and the United States (U.S.). A changing diet pattern and 
nutrition suggestion would cause the increase in the global demand for butter exports. See Section 2 for more details on this. (b) Of all dairy products, the U.S. and the EU have tried to regulate dairy markets primarily through interventions in butter markets. This suggests that butter is representative of the dairy industry in general in terms of studying the links between export prices and macroeconomic and policy factors. (c) Butter is a relatively homogeneous dairy product, so its trade patterns are not easily distorted by product differentiation, especially in international trade that circumvents the negative effects of intensive global competition. (d) According to the OECD-FAO Agricultural Outlook 2019-2028, international reference prices for dairy fat refer to butter of the main exporters in Oceania (New Zealand contributing the most) and Europe. Since 2015, the price of butter is considerably higher than the price of skim milk powder prices because of stronger demand for milk fat globally and is expected to remain a structural feature in future.

The overall objective of this empirical study was to understand global butter price transmission both spatially across different countries and vertically along the supply chain and try to figure out how this is linked to macroeconomic indices, energy prices, input prices, upstream milk prices, and substitute product prices in the short term and long term and how butter export prices of different exporting countries react to shocks to these influencing factors. This should provide policy makers, producers, manufacturers, and exporters with relevant information that has implications for decision making to stabilize the global butter market and protect welfare of different stakeholders along the global butter supply chain. Six drivers, including consumer price index (CPI) for food, nominal exchange rate, fertilizer price, farm-gate milk price, crude oil price, and palm oil price, are incorporated into the analysis along with butter export prices for the U.S., the EU, and New Zealand. It is assumed that decreases in crude oil price, palm oil price, farm-gate raw milk price, and the U.S. dollar appreciation would cause decreases in butter export prices, while increases in CPI for food would cause increases in butter export prices, and the global butter market is well-integrated. Several scenarios were simulated, and hypotheses were examined through this empirical analysis.

The rest of the study is organized as follows: Section 2 provides background and methodology for this paper. Section 3 presents the empirical models and data sources for spatial butter export prices and related influencing factors. Section 4 reports the empirical results to understand the short-term relationships. Section 5 presents the dynamic analysis using general impulse response functions to understand the price linkages and dynamics in the long run. Finally, Section 6 sets out the conclusion and discussion of this paper.

\section{Background and Methodology}

\subsection{Background}

Butter has been characterized as a commodity with a highly concentrated and limited number of major exporters and numerous importers of all dairy products. New Zealand is the leading exporter for butter, followed by the EU. As shown in Figure 1, in 2019, the U.S., the EU-28, and New Zealand accounted for $2.4 \%, 25.2 \%$, and $52.8 \%$ of global butter exports, respectively, accounting for over $80 \%$ of world total butter exports in trade value.

Figure 2 depicts monthly butter export prices for the U.S., the EU, and New Zealand from January 2010 to December 2019. The butter export price of New Zealand, the EU-28, and the U.S. in U.S. dollars was calculated by dividing the total export value in U.S. dollars by the total export weight in kilogram for each country (region). The U.S. and New Zealand butter export prices display a similar pattern prior to 2017, with the price cycle less obvious compared to the EU. Butter export prices for these three countries spiked in mid-2011 and during 2013 to early 2014, with the peak and trough of EU cycles exhibiting a wider range than those of the U.S. and New Zealand. The reasons behind the price patterns could be the following: firstly, unbalanced supply and demand raised export prices to a high level in the global markets when New Zealand's butter prices fluctuated more greatly during 2013 and early 2014. Demand from China increased during 2013 and early 
2014 through acquisition of substantial stocks due to a significant shortfall in its growing domestic supply, while the productions of the U.S., the EU, and New Zealand did not expand at the same rate as demand in China [14-16]. However, prices immediately fell in early 2014, as shown in Figure 2, due to a fall in purchasing demand in China, and increased production among exporters, together with an import ban for EU dairy products imposed by the Russian Federation, led to price remaining at the lower levels until early 2017 [16]. From mid-2016 to late 2018, prices have been rising for exports from the EU and New Zealand. The increase in dairy prices in 2016 and 2017 was due to a slump in milk production in New Zealand and the EU as well as a strong demand for butter. In Oceania, milk production has been limited for several reasons, including low dairy prices in 2015-16, adverse weather conditions related to El Niño, poor pasture conditions, and a contraction of the dairy herd due to higher prices of cull dairy cows in 2016. In the EU, both domestic and international cheese and butter consumption increased, and some key producers reduced their production. [17,18]

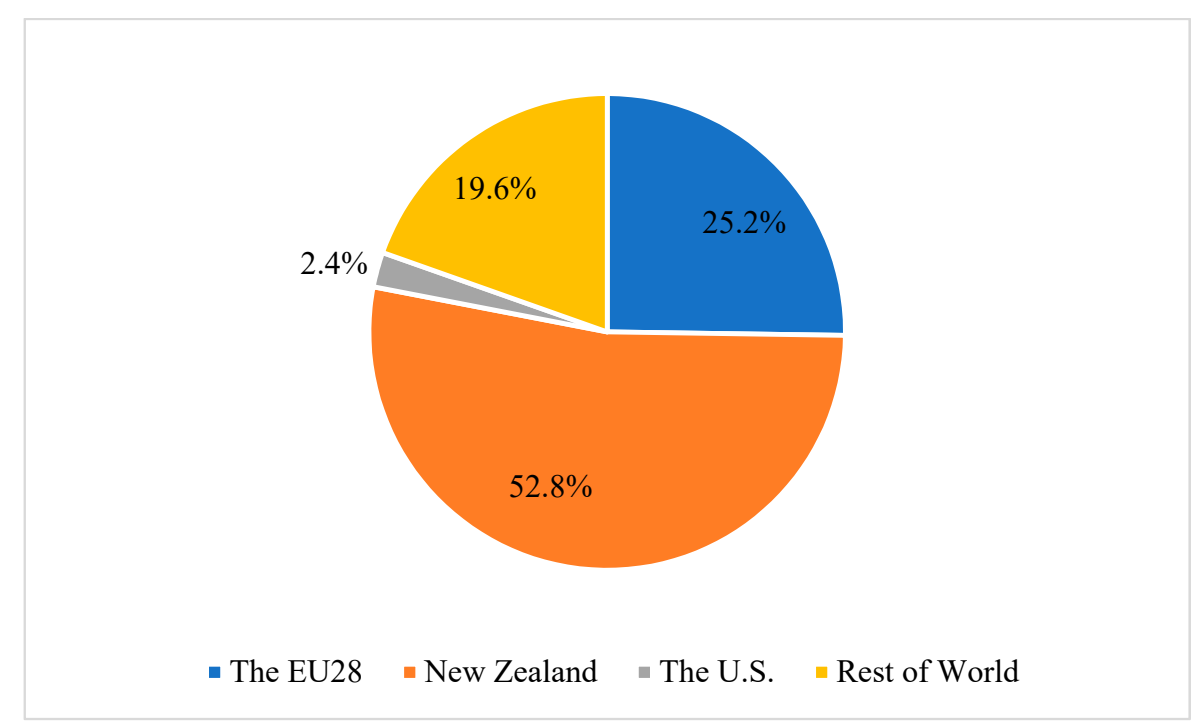

Figure 1. Butter export value and U.S., EU, and New Zealand shares of the global market in 2019 (billon USD). Source: authors' calculation using data from FAOSTAT. Source: Data were calculated by authors using FAOSTAT data accessed in 2021; Intra-EU export was excluded for the EU 28 export.

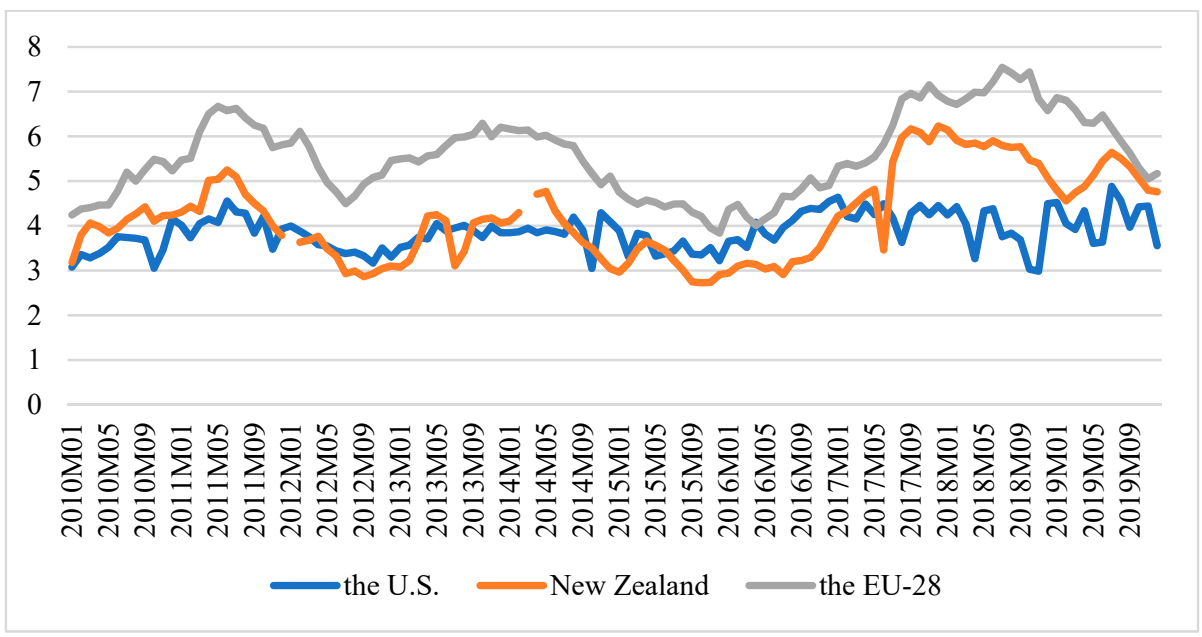

Figure 2. Butter export price of the U.S., the EU, and New Zealand from January 2010 to December 2019 (see Appendix A for data source and calculation). 
In general, the price evolves with similar patterns but at different price levels. U.S. and New Zealand prices have been relatively lower than the EU's price. The reasons for this could be that, first, the EU's price-support mechanism (intervention) that could set a price floor for butter and, second, differences in consumer preferences and geographical proximity to markets. For example, several butter major importers, such as North African and Middle Eastern countries, have preferences towards European butter.

Although some simple co-movement patterns can be seen from Figure 2, the distributions of individual price series are different, and these may be linked to the heterogenous reactions of countries to shocks. This leads to more rigorous econometric analysis to explain why prices may not be well-linked across countries and thus why dairy product markets may or may not be well-integrated in order to reveal factors behind global market integration and hidden price transmission characteristics among the three major players. For example, some studies on market integration for global skim milk powder (SMP) market analyse SMP price transmission among the U.S., the EU, and New Zealand $[4,5,19]$. Other studies considered the impact of crude oil price shock [20] or palm oil price shock [21] on butter prices in one or two regions. However, literature focuses on either on dairy price transmission alone or on one or two factors affecting one dairy product in certain countries without taking main influencing factors. Global butter export market is dynamic and interlinks with various drivers from both home countries and foreign countries. Macroeconomic indicators, such as domestic food inflation and exchange rate; upstream raw material price, such as farm-gate milk price and fertilizer price; substitutes, such as palm oil price; and crude oil price in the energy market may be highly connected to global butter export prices from one country to another.

Linkages between global crude oil price as a proxy for energy costs and agricultural commodity price have been extensively studied in recent years (see Serra and Zilberman [22] for a comprehensive survey), and researchers concluded that crude oil prices might influence agricultural commodity prices in two main ways: (1) oil price increases may result in higher agricultural commodity prices through cost effects because production and distribution consumes crude oil; and (2) high crude oil prices may push up production and consumption of biofuels, thus first increasing prices of grain and other oil prices and then input prices of dairy inputs such as feeds. In terms of dairy products, Huchet-Bourdon [20] found that the correlation for butter (0.46) and whole milk powder (0.47) prices with crude oil prices are the highest when compared with other commodities in the 2000s. Palm oil, a resource used in processing margarine, is a good substitute for butter. Dairy demand may decline due to replacement with other cheaper substitutes in food manufacturing when dairy product prices are high [23]. Therefore, strong price transmission might exist between butter and palm oil in different countries $[21,24]$. Fluctuations in exchange rates are regarded as a major influencing factor that affects the relative prices of exported commodities, thus causing price fluctuations. Exchange rate pass-through to international price, such as import price and export price, can be incomplete and disproportional for different products and countries. The U.S. dollar devaluation has been regarded and empirically studied as one of the main reasons behind the soaring commodity prices [25]. However, there is little agreement on the impacts of the U.S. dollar depreciation on commodity prices [26]. The domestic consumer price index for food indicates a country's food price inflation and deflation status. The export prices of a country can freely deviate from the domestic prices of the same goods and from the export prices of other countries, so the rise in the domestic food inflation will tend to raise the export prices of this country and other countries in absolute value and in relative value to the domestic prices [27]. The inflation of domestic food prices might affect choice of domestic consumption and export ratios, thus influencing export prices.

\subsection{GVAR Model Specification}

The GVAR model first proposed by Pesaran, Schuermann, and Weiner [12] connects country-specific models through multiple channels of international linkages, deciphering 
the size and speed of price transmission upon shocks from domestic and foreign countries or from the global market. As a high-dimensional, cross-sectional time-series model seldom relying on economic theory and restrictions, the GVAR model is effective in analysing the spatial commodity price transmission and in identifying the impacts of various shocks and determinants in a visual way. By construction, the GVAR model allows for interaction among different economies through two channels, namely: (a) the contemporaneous interrelation of domestic variables with foreign-specific variables; and (b) the contemporaneous correlation of shocks across countries.

The GVAR model has been applied extensively in macroeconomics, including but not limited to (see Chudik and Pesaran [13] for comprehensive surveys) studying the factors and shocks affecting global inflation [28], global imbalance [29-32], effects of fiscal and monetary policy [33-39], credit supply shock [40-42], spill overs in the labour market [43], financial market [44], energy market [45], trade [46], and different sectors [47-49], etc. So far, the GVAR model has been applied to agricultural markets twice. Gutierrez et al. [50] demonstrated the possibility of establishing a GVAR model for global wheat export prices to analyse linkages among food commodity prices, energy prices, and financial sectors in the major wheat export countries and found that a reduction of the U.S. stock-to-use ratio, an increase of oil price, and a devaluation of the U.S. dollar will increase global wheat export prices. Pierre and Kaminski [51] studied short-run food price shock propagation in Sub-Saharan Africa (SSA) using the GVAR model. Significant between-country market contagion and rapid regional price shock propagation were found when trade connections exist. They also found that market integration of maize within SSA and with global markets are weak. However, only two papers have applied the GVAR model for agriculture commodity price transmission and explored their dynamics with other influencing factors.

To the best of our knowledge, there is no empirical research on the dairy industry that thoroughly analyses spatial price transmission and interaction with macroeconomic influencing factors. Using GVAR models, price transmission and market dynamics could be addressed and effectively studied with less economic theoretical constraints. This study follows a similar approach to Gutierrez, Piras, and Paolo Roggero [50] and Pierre and Kaminski [51] and proceeds as follows.

The GVAR model comprises two steps: the first step is the construction of the individual unit (countries and regions) models VARX, and the second step is to stack the estimated country models together to form one large Global VAR model.

It is assumed that there are $\mathrm{N}$ cross-section units, for each of which $k$ variables are observed during the time period $t=1,2,3, \ldots, T$. $x_{i t}$ denotes the $k_{i} \times 1$ vector of variables specific to unit $i$ in time period $t . x_{t}=\left(x_{1 t}^{\prime}, x_{2 t}^{\prime}, \ldots, x_{n t}^{\prime}\right)^{\prime}$ denotes the $k \times 1$ vector of all the variables, where $k=\sum_{i=1}^{N} k_{i}$. For the empirical model in this paper, the cross-section units refer to the specific countries and regions defined (i.e., the U.S., the EU, New Zealand, and the Rest of World (RoW)) for research purposes.

Country-specific conditional models are estimated separately. These individual country models explain the domestic variables of a given economy, $x_{i t}$, conditional on countryspecific cross-section averages of foreign variables, collected in the $k^{*} \times 1$ vector

$$
x_{i t}^{*}=\widetilde{W}_{i}^{\prime} x_{t}
$$

for $i=1,2,3, \ldots, N$, where $\widetilde{W}_{i}$ is $k \times k^{*}$ matrix of country-specific weights, typically constructed using data on bilateral foreign trade or capital flows. Both $k_{i}$ and $k^{*}$ are treated as small (typically 4 to 6 ).

$x_{i t}$ is modelled as a VARX* model, namely a VAR model augmented by the vector of the 'star' variables $x_{i t}^{*}$ and their lagged values as Equation (2). Moreover, when country models need to be augmented by global variables $d_{t}$ and its lagged values, in addition to 
country-specific vector of cross-section averages of the foreign variables, the model will be represented as Equation (3).

$$
\begin{gathered}
x_{i t}=a_{i 0}+a_{i 1} t+\sum_{l=1}^{p_{i}} \Phi_{i l} x_{i, t-l}+\Lambda_{i 0} x_{i t}^{*}+\sum_{l=1}^{q_{i}} \Lambda_{i l} x_{i, t-l}^{*}+\varepsilon_{i t} \\
x_{i t}=a_{i 0}+a_{i 1} t+\sum_{l=1}^{p_{i}} \Phi_{i l} x_{i, t-l}+\Lambda_{i 0} x_{i t}^{*}+\sum_{l=1}^{q_{i}} \Lambda_{i l} x_{i, t-l}^{*}+\Psi_{i 0} d_{t}+\sum_{l=1}^{s_{i}} \Psi_{i l} d_{t-l}+\varepsilon_{i t}
\end{gathered}
$$

for $i=1,2, \ldots, N$, where $\Phi_{i l}$, for $l=1,2, \ldots, p_{i}, \Lambda_{i l}$, for $l=0,1,2, \ldots q_{i}$, are $k_{i} \times k_{i}$ and $k_{i} \times k^{*}$ matrices of unknown parameters, respectively. Additionally, $\varepsilon_{i t}$ are $k_{i} \times 1$ error vectors.

For simplicity, it is assumed that $\Psi_{i l}=0$ for $l=0,1,2, \ldots, s_{i}$ in the following derivation. Therefore, let $Z_{i t}=\left(x_{i t}^{\prime}, x_{i t}^{* \prime}\right)^{\prime}$ be $k_{i}+k^{*}$ dimensional vector; thus, Equation (2) can be rewritten as

$$
\mathrm{A}_{i o} \mathrm{Z}_{i t}=a_{i 0}+a_{i 1} t+\sum_{l=1}^{p} \mathrm{~A}_{i l} \mathrm{Z}_{i, t-l}+\varepsilon_{i t}
$$

where

$\mathrm{A}_{i 0}=\left(\mathrm{I}_{k i}-\Lambda_{i 0}\right), \mathrm{A}_{i t}=\left(\Phi_{i l}, \Lambda_{i l}\right)$ for $l=1,2, \ldots, p$.

The estimation of country models GVARX as Equation (3), which allows for cointegration within and across countries (via the star variables), is the first step of the GVAR approach.

Then the deduction is made to get error-correction representation (8): minus $x_{i, t-1}$ on both side of Equation (2); the result is

$$
\Delta x_{i t}=a_{i 0}+a_{i 1} t+\Lambda_{i 0} x_{i t}^{*}-\Lambda_{i 0} x_{i, t-1}^{*}+\Lambda_{i 0} x_{i, t-1}^{*}-x_{i, t-1}+\sum_{l=1}^{p_{i}} \Phi_{i t} x_{i, t-l}+\sum_{l=1}^{q_{i}} \Lambda_{i t} x_{i, t-l}^{*}+\varepsilon_{i t}
$$

Then

$$
\Delta x_{i t}=a_{i 0}+a_{i 1} t+\Lambda_{i 0} \Delta x_{i t}^{*}+\Lambda_{i 0} x_{i, t-1}^{*}-x_{i, t-1}+\sum_{l=1}^{p_{i}} \Phi_{i t} x_{i, t-l}+\sum_{l=1}^{q_{i}} \Lambda_{i t} x_{i, t-l}^{*}+\varepsilon_{i t}
$$

Then

$$
\Delta x_{i t}=a_{i 0}+a_{i 1} t+\Lambda_{i 0} \Delta x_{i t}^{*}-\mathrm{A}_{i 0} \mathrm{Z}_{i, t-1}+\sum_{l=1}^{p} \mathrm{~A}_{i l} \mathrm{Z}_{i, t-l}+\varepsilon_{i t}
$$

Therefore, by rearranging terms, the error-correction representation of Equation (2) as follows are constructed:

$$
\Delta x_{i t}=a_{i 0}+a_{i 1} \mathrm{t}+\Lambda_{i 0} \Delta x_{i t}^{*}-\Pi_{i 0} \mathrm{Z}_{i, t-1}+\sum_{l=1}^{p} H_{i l} \Delta \mathrm{Z}_{i, t-l}+\varepsilon_{i t}
$$

where $\Pi_{i 0}=-\left(\mathrm{A}_{i 0}-\sum_{l=1}^{p} \mathrm{~A}_{i l}\right), H_{i l}=-\sum_{l=1}^{p-1} \mathrm{~A}_{i, l+1}, \Delta=1-\mathrm{L}$ is the first order difference.

The second step of the GVAR approach consists of stacking estimated country models to form one large global VAR model.

Using the $\left(k_{i}+k^{*}\right) \times k$ dimensional 'link' matrices $W_{i}=\left(\mathrm{E}_{i}^{\prime}, \widetilde{W}_{i}^{\prime}\right)$, where $E_{i}$ is $k \times k_{i}$ dimensional selection matrix that select $x_{i t}$, namely $x_{i t}=\mathrm{E}_{i}^{\prime} x_{t}$, and $\widetilde{W}_{i}^{\prime}$ is the weight matrix introduced in Equation (1) to define country-specific foreign star variables. Then

$$
Z_{i t}=\left(x_{i t}^{\prime}, x_{i t}^{* \prime}\right)^{\prime}=W_{i} x_{t}
$$

Then Equation (4) can be written as Equation (10)

$$
\mathrm{A}_{i 0} W_{i} x_{t}=a_{i 0}+a_{i 1} t+\sum_{l=1}^{p} \mathrm{~A}_{i l} W_{i} x_{t-l}+\varepsilon_{i t}
$$


Then Equation (11) is

$$
G_{0} x_{t}=a_{0}+a_{1} t+\sum_{l=1}^{p} G_{l} x_{t-l}+\varepsilon_{t}
$$

where $\varepsilon_{t}=\left(\varepsilon_{1 t}^{\prime}, \varepsilon_{2 t}^{\prime}, \ldots, \varepsilon_{N t}^{\prime}\right)^{\prime}, a_{0}=\left(a_{10}^{\prime}, a_{20}^{\prime}, \ldots, a_{N 0}^{\prime}\right)^{\prime}, a_{1}=\left(a_{11}^{\prime}, a_{21}^{\prime}, \ldots, a_{N 1}^{\prime}\right)^{\prime}$

$$
G_{l}=\left(\begin{array}{c}
\mathrm{A}_{1, l} W_{1} \\
\mathrm{~A}_{2, l} W_{2} \\
\vdots \\
\mathrm{A}_{N, l} W_{N}
\end{array}\right)
$$

If matrix $G_{0}$ is invertible, then by multiplying Equation (6) by $G_{0}^{-1}$ from the left, the solution to the GVAR model is obtained.

$$
x_{t}=b_{0}+b_{1} t+\sum_{l=1}^{p} F_{l} x_{t-l}+G_{0}^{-1} \varepsilon_{t}
$$

where $F_{l}=G_{l} G_{0}^{-1}, b_{0}=a_{0} G_{0}^{-1}, b_{1}=a_{0} G_{0}^{-1}$. Equation (12) can be solved recursively and used for analysing the impulse responses, to compute the forecast error decompositions, or to forecast the $x_{t}$ variables.

\section{Empirical Models and Data}

Understanding the mechanism of butter export price transmission and the interactions with macroeconomic indicators (e.g., exchange rate, CPI for food), the input materials prices (e.g., fertilizer price, farm-gate raw milk price, and crude oil price) and substitute is of vital importance for dairy industry stakeholders and policy makers to tackle the economic shocks. Applying GAVR models on global butter export markets, this study illustrates butter export prices' responses to different sorts of shocks in the short term and in the long term as well as highlights the global butter market integration.

Four VARX models were constructed in this study, one for each of the main export regions: the U.S., the EU, New Zealand, and a RoW regional VARX model specified to represent the effects from all the other countries. China, Japan, Mexico, the Russian Federation, and Ukraine are aggregated as representative of the Rest of World because these countries are major dairy importers or exporters and their relevant data are available to meet the requirements of this study. The 28 member states of the EU, which share agriculture and trade policies under the Common Agricultural Policy (CAP), are regarded as a single exporter, and so butter export prices of the EU exporting to countries outside of the EU-28-member states are constructed and put into analysis.

The country-specific variables include: (1) the index of export prices in U.S. dollars, denoted as $p_{i t}^{e} ;$ (2) the index of fertilizer price in the local currency as $p_{i t}^{f}$; (3) the bilateral exchange rate against the U.S. dollar, denoted as $e_{i t} ;(4)$ the consumer food price index, $C P I_{i t}$, which reflects food inflation in each country; and (5) farm-gate raw milk price as $p_{i t}^{m}$. Although variables related to production are not included due to unavailable of monthly data. Nevertheless, the model is still effective to analyse the effect of supply shocks. For example, production shortfalls result from extreme weather or sudden supply-side policy change can still be analysed by imposing a corresponding farm-gate milk price change in the specific country.

The foreign-specific variables are established as a weighted average of the countryspecific variables. The weights $W_{i}$ are country-specific weights computed as averages of shares of exports in total world exports from 2010 to 2018. Therefore, the foreignspecific variables include: (1) the average of competitors' export prices, $p_{i t}^{e *}=\sum_{i \neq j} w_{j} p_{j t^{e}}^{e} ;$ (2) the average of countries bilateral exchange rate, $e_{i t}^{*}=\sum_{j \neq i} w_{j} e_{j t}$; (3) the average of the 
food price indexes, $C P I_{i t}^{*}=\sum_{j \neq i} w_{j} C P I_{j t}$; and (4) the average of farm-gate raw milk prices, $p_{i t}^{m *}=\sum_{i \neq j} w_{j} p_{j t}^{m}$

In GVAR model analysis, the global variables are defined as ones that are set to be endogenous in one country, could impact the system of each country, and are of vital importance to all countries. The dairy industry depends on energy in that oil and energy are necessary for the production of milk, dairy products, and transportation of the products, thus directly influencing butter export prices. Therefore, the dairy market can be affected by changes in energy prices, such as world crude oil price, denoted as $p_{t}^{o}$. Butter has long been consumed by western people, and its price is relatively high and volatile compared with other fat sources. Palm oil is versatile and the most produced vegetable oil, with a share of more than $30 \%$ of global vegetable oil production (USDA 2014). Both butter and palm oil are sources of fat. Margarine, which can be produced using palm oil, is a good substitute for butter, and it is much cheaper than butter as cooking oil. The major butter export destinations of New Zealand, such as China and other Asian countries, are main palm oil consumers and importers, so palm oil price should influence New Zealand butter price more and be endogenously determined in New Zealand. Therefore, international butter export prices can be influenced by palm oil prices, denoted as $p_{t}^{p}$. In the constructed GVAR model, the crude oil price is set to be endogenous in the U.S. VECX model following most of the GVAR empirical studies $[50,52]$ and palm oil price is set to be endogenous in the New Zealand VECX model. Therefore, the variable vectors are as following:

The domestic variables vectors for the EU and New Zealand VARMs (VECMs):

$$
x_{i t}=\left(p_{i t}^{e}, e_{i t}, p_{i t}^{f}, C P I_{i t}, p_{i t}^{m}\right), \text { where } i=1 \text { and } 2
$$

The domestic variables vectors for the U.S. VARM (VECM):

$$
x_{0 t}=\left(p_{0 t}^{e}, p_{0 t}^{f}, C P I_{0 t}, p_{0 t}^{m}\right),
$$

The domestic variables vector for Rest of world VARM (VECM):

$$
x_{3 t}=\left(e_{3 t}, p_{3 t}^{f}, C P I_{3 t}\right),
$$

The foreign variables vectors for the U.S., the EU, New Zealand, and Rest of World VARMs (VECMs):

$x_{i t}^{*}=\left(p_{i t}^{e *}, e_{i t}^{*}, C P I_{i t}^{*}, p_{i t}^{e *}, p_{i t}^{m *}\right)$, where $i=0, \ldots, 3$

Note: the local fertilizer prices were converted by exchange rates from world fertilizer prices, so foreign counterpart fertilizer variable was excluded from the model to avoid multicollinearity problems.

The global variables vectors for VARMs (VECMs):

$$
d_{t}=\left(p_{i t}^{c o}, p_{i t}^{p o}\right)
$$

Put the above-mentioned variable vectors into the following model specification:

$$
x_{i t}=a_{i 0}+a_{i 1} t+\sum_{l=1}^{p_{i}} \Phi_{i l} x_{i, t-l}+\Lambda_{i 0} x_{i t}^{*}+\sum_{l=1}^{q_{i}} \Lambda_{i l} x_{i, t-l}^{*}+\Psi_{i 0} d_{t}+\sum_{l=1}^{s_{i}} \Psi_{i l} d_{t-l}+\varepsilon_{i t}
$$

for $i=0,1,2,3$, which represent the U.S., the EU, New Zealand, and RoW, respectively; where $\Phi_{i l}$, for $l=1,2, \ldots, p_{i}, \Lambda_{i l}$, for $l=0,1,2, \ldots q_{i}$, are $k_{i} \times k_{i}$ and $k_{i} \times k^{*}$ matrices of unknown parameters, respectively. Additionally, $\varepsilon_{i t}$ are $k_{i} \times 1$ error vectors.

Monthly data from January 2010 to December 2019 are used for all variables in this study. The butter export price of New Zealand, the EU-28, and the U.S. in U.S. dollars was calculated using the equation: $p_{i t}^{e}=\frac{V_{i t}^{e}}{Q_{i t}^{e}}$, where $V_{i t}^{e}$ is the total export value in 
U.S. dollars, $Q_{i t}^{e}$ is the total export weight in kilogram, and $i$ symbolizes the exporters, namely, the EU-28, New Zealand, the U.S., and the RoW. All the variables used in this study are transformed to natural logarithm form of their indexes using the average value of period January/2010 to December/2010 as the base year. The data information is detailed in Table A1 of Appendix A, and a summary statistics table is shown as Table A2 in Appendix A. Agri-food commodities usually have strong seasonality, yet butter is a product that has a long shelf-life and could be stored for future use. Accordingly, in this study, the GVAR model is constructed using the unadjusted butter export price index series.

In this analysis, the software MATLAB 2019 (a) was used for statistical analysis, and Microsoft Excel and R were used for the depiction of figures. Specifically, the GVAR Toolbox 2.0 developed by Smith and Galesi [53] was applied for the GVAR model estimation and analysis.

\section{Empirical Results and Analysis}

The weights for constructing foreign variables are of vital importance to the analysis of the dynamics of the model. The dairy export flows between studied countries by value are constructed as the fixed weights to indicate the mutual trade relations among studied countries in this study, as outlined in Table 1. It can properly signal bilateral dairy trade linkages for the studied countries in this GVAR butter export price model, which includes merely four exporters. As the weights show, the EU and New Zealand's export share to the U.S. is higher than the U.S.'s share in the EU and New Zealand markets. However, the rest of the world accounts for most dairy imports from the U.S., the EU, and New Zealand.

Table 1. Trade weights based on total dairy products export values.

\begin{tabular}{ccccc}
\hline Country & The U.S. & The EU 28 & New Zealand & RoW \\
\hline The U.S. & 0 & 0.05039 & 0.039375 & 0.910235 \\
The EU & 0.309259 & 0 & 0.016701 & 0.67404 \\
New Zealand & 0.165426 & 0.071756 & 0 & 0.762818 \\
RoW & 0.704301 & 0.289934 & 0.005766 & 0 \\
\hline
\end{tabular}

Note: Trade weights are computed using the following equation: $W_{i j}=\frac{1}{9} \sum_{t=2010}^{2018} \frac{E x V_{t}^{i j}}{E x V_{t}^{i v o r l d}}$, where $i$ represents the export countries, $j$ represents the partner countries, $E x V_{t}^{i j}$ represents the export values of the reporter $i$ to partner $j$ in the year $t$, and $E x V_{t}^{\text {iworld }}$ represents the export values of the reporter $i$ exporting to the world in the year $t$. Therefore, the trade weight is calculated as the average of the share of reporters' dairy export value to partners in the reporters' dairy export value to the world from 2010 to 2018. In the above table, the exporters (reporters) are displayed in the rows, and each row sums to 1. Data to compute these are UN Comtrade data extracted from USDA-GATS dataset. Source: USDA-GATS. RoW, the Rest of World.

Testing the stationarity is the first and a necessary step to analysing time series data. The results of Augmented Dickey-Fuller (ADF) unit root test are shown in Table 2. As indicated by the ADF tests, all the series except export price of the U.S. and CPI for food of New Zealand included in this model do not reject the null hypothesis of non-stationarity and are integrated at the first difference level; thus, all the timeseries in the analysis are I (1). Therefore, the variables in each country or region might have cointegrating relationships, and the Maximum Eigenvalue Statistic and Trace Statistic are estimated to determine the cointegrating relationships. 
Table 2. Augmented Dickey-Fuller (ADF) unit root tests statistics for domestic and foreign variables.

\begin{tabular}{|c|c|c|c|c|}
\hline Variables & The U.S. & The EU-28 & New Zealand & RoW \\
\hline$p_{i t}^{e}($ with trend) & -3.56 & -1.93 & -2.15 & - \\
\hline$p_{i t}^{e}$ (no trend) & -3.46 & -2.10 & -1.92 & - \\
\hline D. $p_{i t}^{e}$ & -13.91 & -6.70 & -7.61 & - \\
\hline$e_{i t}$ (with trend) & - & -2.41 & -2.86 & -1.85 \\
\hline$e_{i t}($ no trend $)$ & - & -1.54 & -1.56 & -0.98 \\
\hline D. $e_{i t}$ & - & -5.53 & -6.47 & -6.30 \\
\hline$p_{i t}^{f}$ (with trend) & -2.68 & -2.90 & -2.89 & -2.85 \\
\hline$p_{i t}^{f}($ no trend $)$ & -1.25 & -1.96 & -2.06 & -2.81 \\
\hline D. $p_{i t}^{f}$ & -7.89 & -7.82 & -8.23 & -7.45 \\
\hline$C P I_{i t}$ (with trend) & -1.84 & -2.10 & -4.04 & -2.17 \\
\hline$C P I_{i t}$ (no trend) & -3.06 & -0.99 & -2.29 & -0.68 \\
\hline D.CPI & -4.48 & -7.46 & -7.16 & -5.39 \\
\hline$C P I_{i t}$ (with trend) & -3.06 & -2.27 & -2.52 & - \\
\hline$C P I_{i t}$ (no trend) & -2.83 & -2.31 & -2.58 & - \\
\hline D.CPI $I_{i t}$ & -7.18 & -6.11 & -4.34 & - \\
\hline$p_{i t}^{m}$ (with trend) & -1.85 & -3.35 & -2.27 & -2.14 \\
\hline$p_{i t}^{m}($ no trend $)$ & -1.90 & -3.24 & -2.49 & -2.33 \\
\hline D. $p_{i t}^{m}$ & -6.10 & -13.82 & -11.80 & -5.27 \\
\hline$p_{i t}^{e *}$ (with trend) & -1.87 & -1.86 & -1.86 & -2.41 \\
\hline$p_{i t}^{e *}$ (no trend) & -0.97 & -0.97 & -0.98 & -1.53 \\
\hline D. $p_{i t}^{e *}$ & -6.27 & -6.30 & -6.25 & -5.52 \\
\hline$e_{i t}^{*}$ (with trend) & -2.87 & -2.96 & -2.91 & -2.84 \\
\hline$e_{i t}^{*}($ no trend $)$ & -2.87 & -2.98 & -3.00 & -1.67 \\
\hline D. $e_{i t}^{*}$ & -7.48 & -7.66 & -7.55 & -7.88 \\
\hline$p_{i t}^{f *}($ with trend) & -2.19 & -2.03 & -2.19 & -2.39 \\
\hline$p_{i t}^{f *}($ no trend $)$ & -0.68 & -0.89 & -0.74 & -1.92 \\
\hline D. $p_{i t}^{f *}$ & -5.69 & -5.43 & -5.76 & -6.98 \\
\hline$C P I_{i t}^{*}$ (with trend) & -3.17 & -3.02 & -3.08 & -3.18 \\
\hline$C P I_{i t}^{*}$ (no trend) & -3.18 & -2.80 & -2.94 & -3.13 \\
\hline D.CPI $I_{i t}^{*}$ & -4.91 & -7.12 & -6.49 & -5.72 \\
\hline$p_{i t}^{m *}$ (with trend) & -3.17 & -3.02 & -3.08 & -3.18 \\
\hline$p_{i t}^{m *}$ (no trend) & -3.18 & -2.80 & -2.94 & -3.13 \\
\hline D. $p_{i t}^{m *}$ & -4.91 & -7.12 & -6.49 & -5.72 \\
\hline$p_{i t}^{p o}$ (with trend) & & & -3.30 & - \\
\hline$p_{i t}^{p o}($ no trend $)$ & & & -1.86 & - \\
\hline D. $p_{i t}^{p o}$ & & & -3.57 & - \\
\hline$p_{i t}^{c O}$ (with trend) & -2.22 & - & - & - \\
\hline$p_{i t}^{c o}($ no trend $)$ & -1.63 & - & - & - \\
\hline D. $p_{i t}^{c o}$ & -6.95 & - & - & - \\
\hline
\end{tabular}

Note: The $95 \%$ critical values of variables with trend and without trend are -3.45 and -2.89 , respectively.

For each country or region's VARX model, the orders of $p$ and $q$ are selected using the AIC criteria based on the pre-constraint $4 \geq p_{i}, q_{i} \geq 1$. To find appropriate lag orders, it is assumed that the model has both an unrestricted intercept and a co-trending restriction to each country or region model. The results shown in Table 3 indicate that the $p$ and $q$ selected for VARX models of the U.S. and the EU-28 are constrained to be 4 by the pre-constraint $4 \geq p_{i}, q_{i} \geq 1$. For the U.S., the EU, and New Zealand, the number of cointegrating relationships in their VECMX models are adjusted to 1, 1, and 1 respectively, while for the rest of the world, there is no cointegrating relation among the variables. 
Table 3. VARX order and number of cointegrating relationships and F statistics of weak exogeneity test at the $5 \%$ significant level.

\begin{tabular}{cccccccccccc}
\hline & & \multicolumn{3}{c}{ VARX Order } & \multicolumn{5}{c}{ F Statistics of Weak Exogeneity Test } \\
\hline Country & $p$ & $q$ & $\begin{array}{c}\text { Adjusted Cointegrating } \\
\text { Relations }\end{array}$ & $\begin{array}{c}\text { Critical } \\
\text { Value }\end{array}$ & $p_{i t}^{e *}$ & $e_{i t}^{*}$ & $C P I_{i t}^{*}$ & $p_{i t}^{m *}$ & $p_{i t}^{p o}$ & $p_{i t}^{c o}$ \\
\hline The U.S. & 4 & 4 & 1 & 3.93 & 1.85 & 1.54 & 0.36 & 9.95 & 1.77 \\
The EU-28 & 4 & 4 & 1 & 3.93 & 0.65 & 0.10 & 8.66 & 0.46 & 1.20 & 0.09 \\
New Zealand & 1 & 1 & 1 & 3.93 & 0.04 & 0.00 & 0.59 & 0.01 & - & 0.35 \\
RoW & 2 & 1 & 0 & 3.93 & 1.85 & 1.54 & 0.36 & 9.95 & 1.77 & - \\
\hline
\end{tabular}

The important assumption underlying the GVAR model estimation is the weak exogeneity of the country-specific foreign variables and the global variables with respect to the long-term parameters of the conditional model. The weak exogeneity was tested as described in Harbo et al. [54]. The results of the F statistics of the weak exogeneity test, as shown in Table 3, indicated that the null hypothesis of weak exogeneity for most foreign-specific variables cannot be rejected at the significance level of $5 \%$. However, it should be noted that EU CPI for food and farm-gate raw milk price of the U.S. might not be weakly exogenous. The GVECM generally satisfied the condition to do comparative studies on the relationship between country-specific and foreign-specific variables and to conduct the impulse responses analysis.

The effects of foreign-specific variables on corresponding domestic variables could be analysed with the cointegrating VECMX being performed. The results of the contemporaneous effects of foreign variables on domestic counterparts along with White's heteroscedastic robust $t$-statistics are reported in Table 4 The contemporaneous effects could be interpreted as the impact elasticities to show the short-term impact of the foreign-specific variables on the domestic counterparts [12,55]. In the VARX models for New Zealand, the exchange rate contemporaneous effects estimations are positive and statistically significant. So, the world exchange rate against the U.S. dollar has positive impacts on the bilateral exchange rate between the U.S. dollar and New Zealand in the short term. The CPI for food coefficients in the U.S. and RoW models are positive and statistically significant, which indicates that the world CPI for food has a positive impact on the CPI for food in the U.S. and in the RoW in the short term.

Table 4. Contemporaneous effects of foreign variables on domestic counterparts.

\begin{tabular}{ccccc}
\hline Country & $p_{i t}^{e^{*}}$ & $\boldsymbol{e}_{i t}^{*}$ & $\boldsymbol{C P I}_{i t}^{*}$ & $p_{i t}^{\boldsymbol{i}^{*}}$ \\
\hline \multirow{2}{*}{ The U.S. } & -0.02 & - & 0.20 & 0.38 \\
& $(-0.08)$ & & $(4.67)$ & $(2.30)$ \\
EU-28 & 0.00 & 0.16 & 0.14 & 0.06 \\
& $(0.02)$ & $(1.79)$ & $(1.64)$ & $(1.43)$ \\
New Zealand & 0.06 & 0.46 & 0.15 & 0.28 \\
& $(0.75)$ & $(4.92)$ & $(1.26)$ & $(1.76)$ \\
RoW & - & 0.17 & 0.62 & - \\
\hline
\end{tabular}

Note: In parentheses, White's heteroscedastic robust $t$-statistics are given.

\section{The Generalized Impulse Response Analysis}

The GVAR model established in this study is dynamically stable with 16 eigenvalues equal to unity and with the remaining moduli less than unity. The eigenvalues in moduli are decreasing to zero gradually; thus, it is expected that Generalized Impulse Response Functions (GIRFs) will converge towards a steady-state equilibrium quickly.

Six external shocks were simulated to analyse the dynamic characteristics of the estimated Global Vector Error Correction Model as listed below, and the GIRFs of butter export prices for the various regions are presented and analysed with a focus on the first three years after the shock. 
(1) A one-standard-error positive shock to butter export price

(2) A one-standard-error negative shock to palm oil price

(3) A one-standard-error negative shock to exchange rate

(4) A one-standard-error positive shock to CPI for food

(5) A one-standard-error negative shock to farm-gate raw milk price

(6) A one-standard-error negative shock to crude oil price

The standard errors of VECMX* residuals are shown in Table 5.

Table 5. Standard errors of VECMX* residuals.

\begin{tabular}{cccccccc}
\hline & $p_{i t}^{e}$ & $e_{i t}$ & $p_{i t}^{f}$ & $C_{\text {PI }}$ & $p_{i t}^{m}$ & $p_{i t}^{c o}$ & $p_{i t}^{p o}$ \\
\hline The U.S. & 0.075 & & 0.052 & 0.002 & 0.030 & 0.051 & \\
The EU-28 & 0.031 & 0.014 & 0.049 & 0.002 & 0.010 & & \\
New Zealand & 0.072 & 0.020 & 0.066 & 0.008 & 0.060 & & 0.045 \\
Rest of World & & 0.021 & 0.066 & 0.005 & & & \\
\hline
\end{tabular}

\subsection{Spatial Price Transmission and Market Integration in the Global Butter Export Market}

The first shock is imposed on the butter export price to analyse the spatial price transmission. This is a typical shock that could affect not only home country but other foreign countries, which reveals the characteristics of market integration for world butter export market. Market integration describes market mechanism in which demand and supply shocks are transmitted, rapidly and smoothly, from one region (market) to another or among different regions (markets) with prices in these regions (markets) moving together in the long term [56]. An analysis of price transmissions in butter export prices among the three major exporters could indicate whether there is market integration and price sensitivity to global shocks. Theoretically, a positive shock to butter export price for one country will be swiftly transmitted on a similar scale to butter export prices for the other countries if the global butter export market is well-integrated, while the transmission will be disproportional or has less spill over effects if butter export prices are not well-integrated.

Figure 3 depicts the time profile of GIRFs of butter export prices after a positive shock and how this shock to one country spreads around the world. The results illustrate that a positive shock to one country's butter export price will raise butter export prices in all countries, yet only its own country's butter export price rises statistically significantly, with $90 \%$ bootstrap error bounds. In the EU, the EU butter price's response to its own price shock is $+3 \%$, and then, the response stabilises at a level of $+2.9 \%$ after eight months. In New Zealand, the New Zealand's response of its own price shock is $+6.8 \%$ instantly after a positive shock, and then, the response stabilises at a level of +4.8 after eight months. In the U.S., its butter export price responds at a level of $+6.4 \%$ immediately after the shock, and then, the response stabilises at a level of $+2.3 \%$ after 12 months. Specially, the positive shock to U.S. butter export price raises New Zealand butter export price for the first two months at a level of $+1 \%$ significantly. The positive shock to New Zealand butter export price raises EU butter export price for the first four months at a level of $0.5 \%$ significantly. 

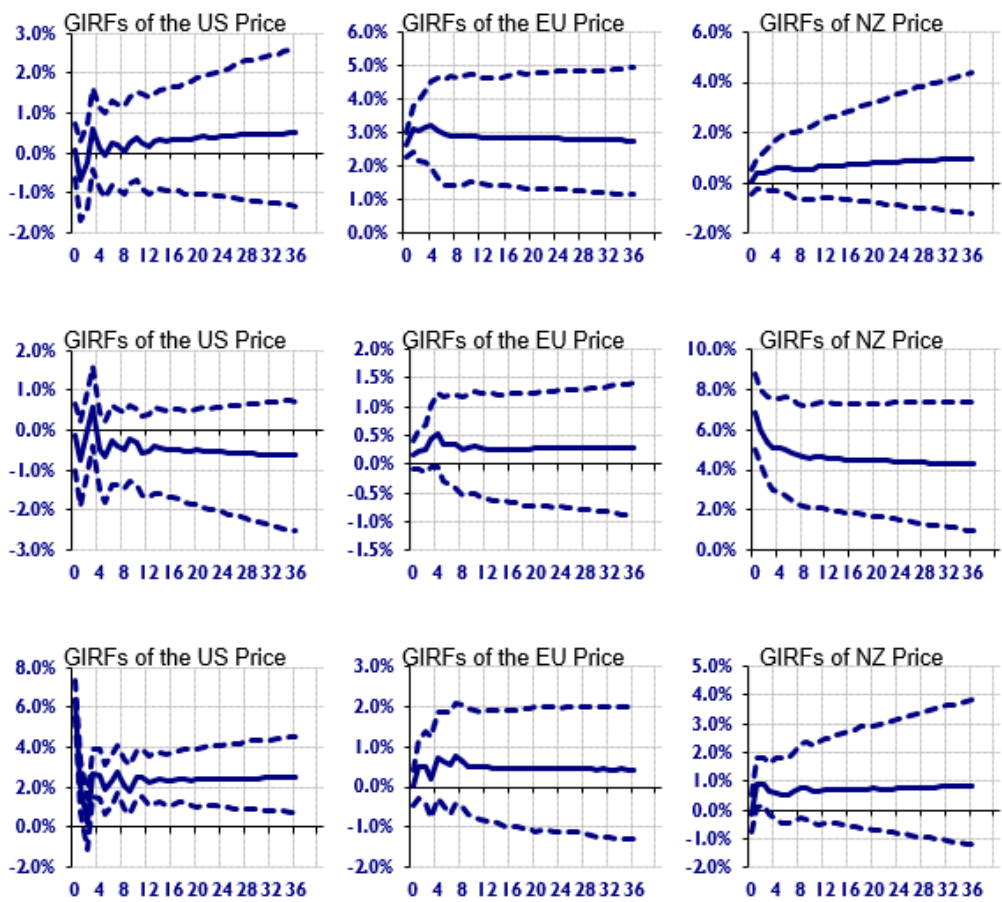

Figure 3. Generalized impulse response of butter export prices after a positive one-standard-error shock to butter export prices of the EU (top), New Zealand (middle), and the U.S. (bottom) (bootstrap median estimates with $90 \%$ bootstrap error bounds).

To sum up, the spatial price shock spill overs are weak from one exporting country to another one, and global butter export markets are not well-integrated. New Zealand butter export prices are more responsive to butter export price shocks in global market.

\subsection{The Impacts of Crude Oil Price Shock}

The impact of a negative global crude oil price shock on the dynamics of butter export prices were analysed, the results of which are reported by time profile of GIRFs in Figure 4. The negative responses of butter export prices in all countries are not statistically significant. An overshoot in responses of the U.S. and New Zealand export prices to negative crude oil shock over time is displayed in GIRFs, while the response of EU butter export price is converging to zero over time. The reasons could be that U.S. cows are corn-fed in large and industrialized farms that consume more energy, and New Zealand butter is exportoriented, which relies on international transportation. Corn is extensively used in making biofuels, while international transportation requires energy commodities, such as crude oil. Thus, the U.S. and New Zealand butter export prices are more subject to crude oil price shocks.
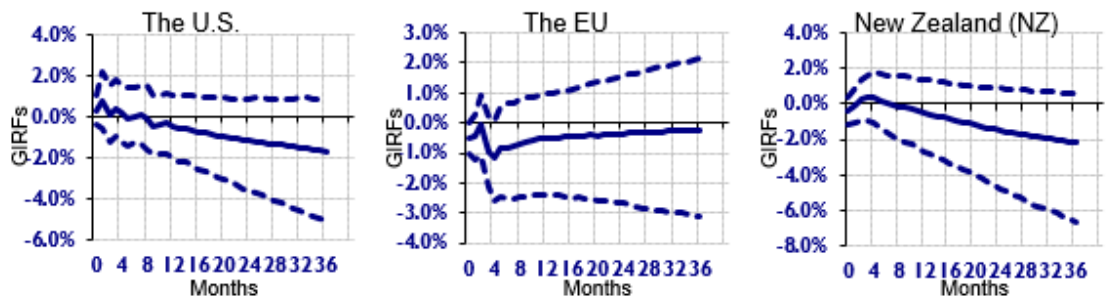

Figure 4. Generalized impulse responses of butter export prices of the U.S., the EU, and New Zealand, respectively, after a negative one-standard-error shock to crude oil price (bootstrap median estimates with $90 \%$ bootstrap error bounds). 
However, the response of butter export prices to crude oil price shocks is slightly different from previous studies on other agri-food products in which statistically significant positive relationships between crude oil price and other agricultural commodities were found. The results in this study imply that, unlike other commodities such as wheat, vegetable oils, and maize, influence of crude oil price shocks on butter export prices of major exporters is not as strong as other agricultural commodities. The reason behind this could be due to less dependence on fuel in the production, supply, and distribution processes for butter.

\subsection{The Impacts of Palm Oil Price Shock}

Over the years, global palm oil production has increased, while butter production has remained relatively stable. Moreover, many dairy import countries, such as China, India, and Japan, are not traditional butter-consumption countries and are quite price sensitive to butter. Palm oil is also used as a main fat source due to its lower price, making butter less competitive in these countries. It is necessary to evaluate whether a negative shock to palm oil price will result in decreases in butter export prices for the U.S., the EU, and New Zealand.

The time profiles of GIRFs of butter export prices after a negative palm oil price shock are illustrated in Figure 5. A negative shock to palm oil price instantly causes decreases in U.S. butter export price by $0.7 \%$, and the effects continue over time. As for the EU, its butter export price response is unusual, with a slight increase by $1 \%$ for the first four months, and then, the response dies down to zero. Different from New Zealand and the U.S., the EU is both a major palm oil importer and exporter, and its major extra EU butter export destinations, such as the U.S. and Middle Eastern countries, merely import palm oil. Accordingly, the response of EU butter export prices cannot last for long. In New Zealand, butter export price decreases by around $1.4 \%$ for the first few months, and then, the impacts of palm oil price shock converge to zero over time. However, responses in all countries are not statistically significant, which indicates that palm oil prices have weak impacts on butter export price.
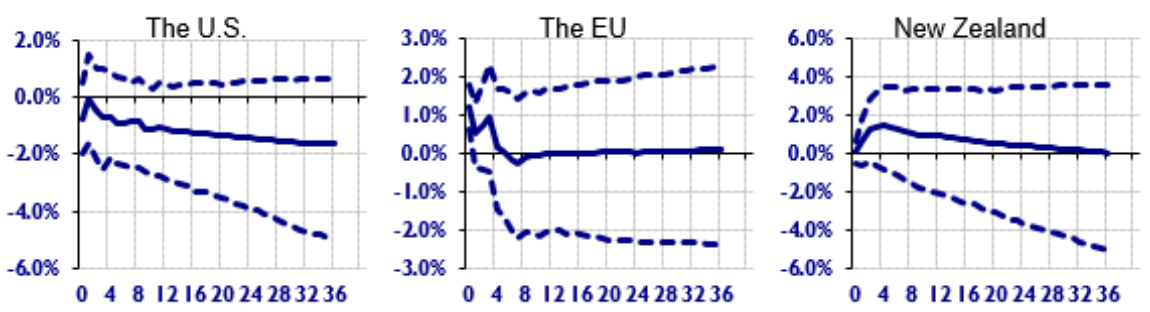

Figure 5. Generalized impulse response of butter export price after a negative one-standard-error shock to palm oil price (bootstrap median estimates with $90 \%$ bootstrap error bounds).

\subsection{The Impacts of Exchange Rate Shock}

This paper evaluates whether U.S. dollar depreciation will lead to decrease of butter export prices and deciphers whether the exchange rate pass-through to butter export prices for different countries is incomplete and disproportional. The exchange rate of local currency per U.S. dollar represents the relative price relationship of the local currency and the U.S. dollar. A negative shock to the exchange rate indicates the depreciation of U.S. dollar or the appreciation of the local currency against the U.S. dollar.

Figures 6-8 outline the responses of butter export prices to a one-standard-error negative shock to the exchange rate of local currency per U.S. dollar, which simulates a relative depreciation of the U.S. dollar and appreciation of local currency. A negative shock to exchange rate of the EU is accompanied by a decline in butter export prices, with statistically significant U.S. butter export price decline and an increase in butter export prices of the EU for the first two months. A negative shock to the exchange rate of the New Zealand dollar per U.S. dollar almost has no impact on butter prices for studied exporters, 
and its effects on other countries are almost zero, as illustrated in Figure 7. A negative shock to exchange rate of the RoW results in an increase of butter export prices in the EU and New Zealand by $1.8 \%$ and $1.6 \%$, respectively, although the impact is not statistically significant as shown in Figure 8.
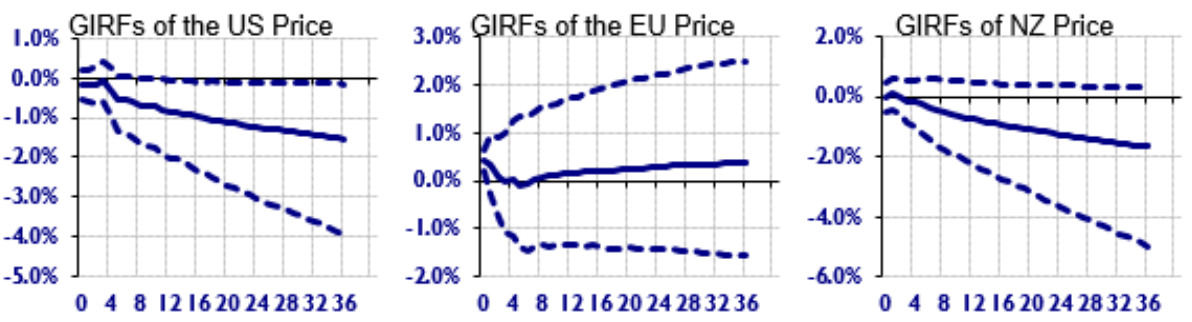

Figure 6. Generalized impulse response of butter export prices after a negative one-standard-error shock to exchange rate of the euro per U.S. dollar (bootstrap median estimates with $90 \%$ bootstrap error bounds).
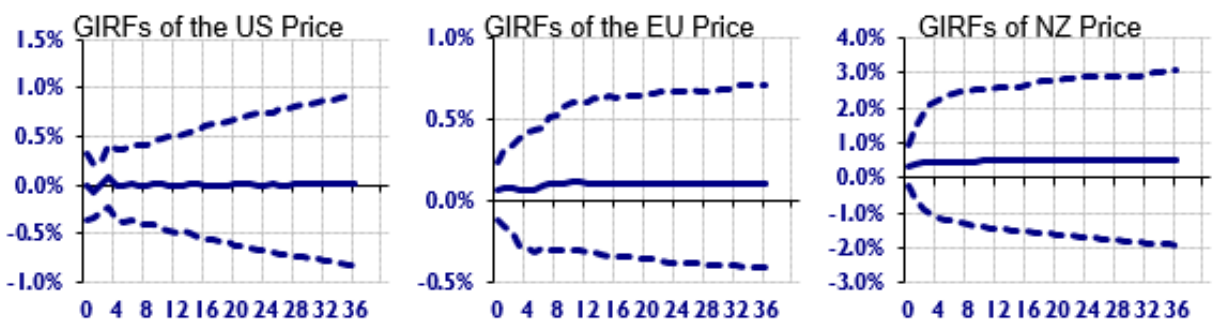

Figure 7. Generalized impulse response of butter export prices after a negative one-standard-error shock to exchange rate of New Zealand dollar per U.S. dollar (bootstrap median estimates with $90 \%$ bootstrap error bounds).
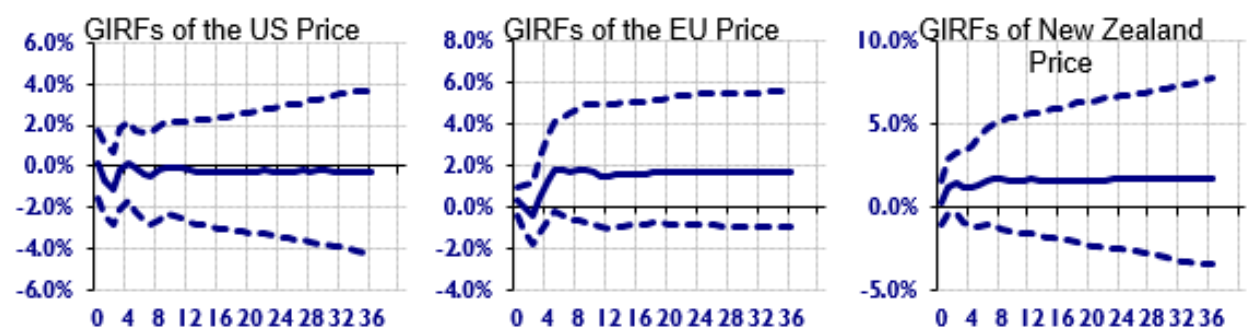

Figure 8. Generalized impulse response of butter export prices after a negative one-standard-error shock to exchange rate of the aggregated RoW's currency per U.S. dollar (bootstrap median estimates with $90 \%$ bootstrap error bounds).

\subsection{The Impacts of CPI for Food Shocks}

Figure 9 illustrates the time profiles of butter export prices' GIRFs after a one-standarderror positive shock to CPI for food index. Butter export prices of different countries respond to the simulated positive shock to different countries' food CPI in different directions. A positive shock to food CPI of the EU and to food CPI of the rest of the world does not have significant impact on butter export prices in all countries. New Zealand butter export price responds negatively after a positive shock to New Zealand's food CPI. Butter export prices of the U.S. and New Zealand increase by $5 \%$ and continue to increase over time after a positive shock to U.S. food CPI. 



Figure 9. Generalized impulse response of butter export prices after a positive one-standard-error shock to CPI for food of the EU (top), New Zealand (row 2), the U.S. (row 3), and the RoW (bottom) (bootstrap median estimates with $90 \%$ bootstrap error bounds).

Theoretically, rising CPI indicates that domestic prices will rise in general. However, butter is a typical agricultural product that is not only tradeable but also suitable for storage. The direction of impact of CPI for food on butter export prices might be reversed given the countries' CPI for food basket and the ratio between its butter's domestic consumption and export. CPI for food basket may compose different food products, and their contribution to CPI varies, too: (a) for export-oriented, open, and small countries, such as New Zealand, their export price will mainly be influenced by food CPI in the main export destinations. Inflations in its destinations will stimulate the exports of New Zealand; thereafter, its export prices will rise. However, as a small economy, inflation of New Zealand hardly affects other countries' export prices, and changes in its own CPI for food may not affect butter export prices directly; (b) for high domestic butter-consumption countries, such as the U.S. $(99 \%)$, the increase in CPI for food might lead to decreases in export volumes and therefore increases in the export prices, and domestic food price inflation rather than food price inflation from other countries will have more impact on the butter export prices; and (c) while for the EU, with active intra-EU trade and relatively lower reliance on butter exports and imports, its butter export price is hardly affected by CPI for food.

\subsection{The Impact of Farm-Gate Milk Price Shock}

A negative shock to farm-gate raw milk prices of each country is simulated to evaluate the price transmission and spill over effects from upstream raw material price to butter 
export prices. The GIRFs of butter export prices in studied countries after simulated shocks are depicted in Figure 10. A decline in EU farm-gate milk price is accompanied by a statistically significant decline in EU butter export prices by $1.7 \%$ after around four months, in New Zealand butter export prices by around 1.3\% after around six months, and in U.S. butter export prices by $0.7 \%$ after around eight months. A negative shock to New Zealand farm-gate milk price leads to statistically significant decreases in New Zealand butter export prices by $3 \%$ after eight months and continues to overshoot over time, and it also leads to statistically significant decreases in U.S. butter export price by over $1.1 \%$ after four months. However, responses of butter export prices in all countries after a negative shock to U.S. farm-gate milk price are not statistically significant. The price transmission from farm-gate raw milk prices to butter export prices is strong, swift, and persistent. Shocks to one country's farm-gate raw milk price not only affect home country but also affect other foreign countries.
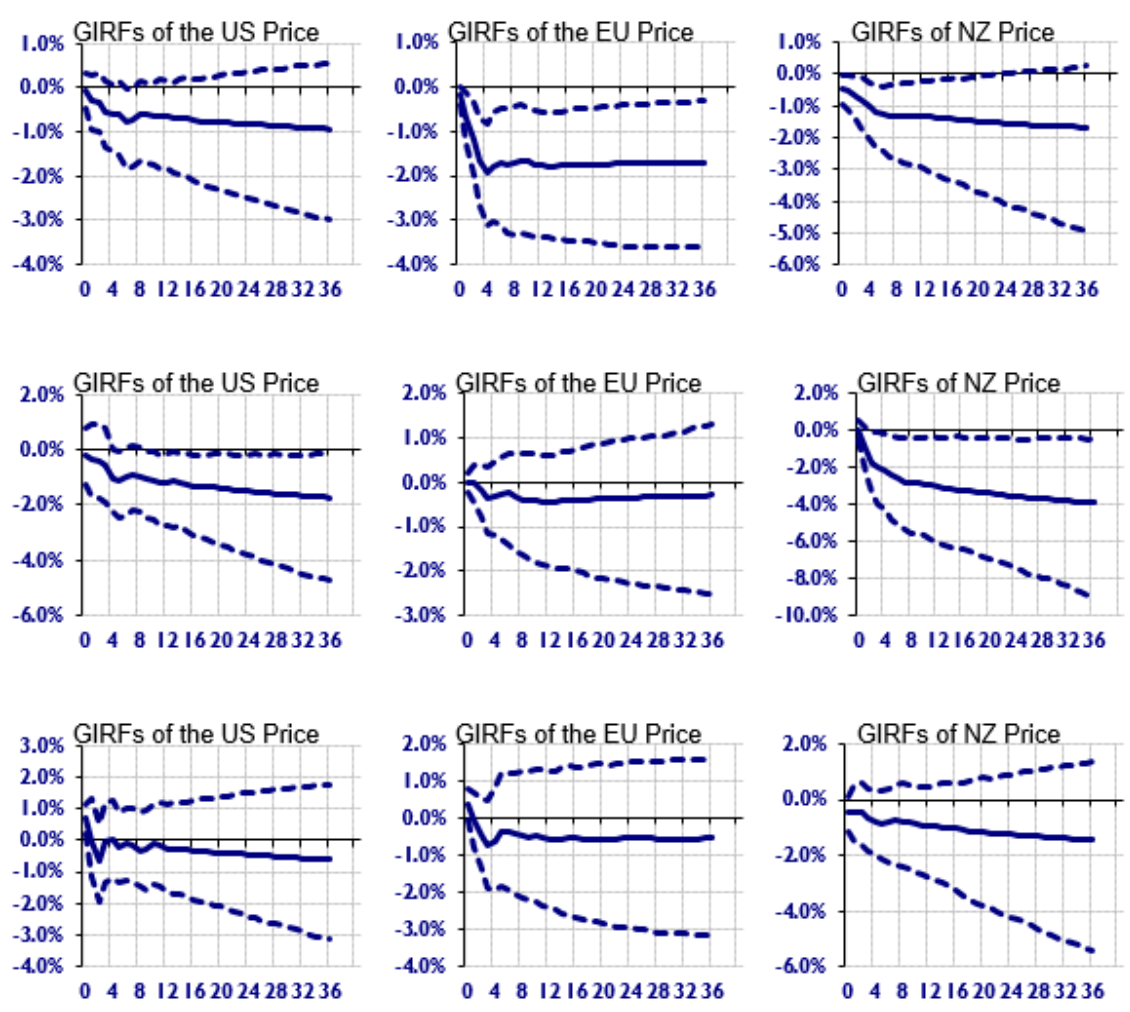

Figure 10. Generalized impulse response of butter export prices after a positive one-standard-error shock to farm-gate milk price of the EU (top), New Zealand (row 2), and the U.S. (bottom) (bootstrap median estimates with $90 \%$ bootstrap error bounds).

\section{Conclusions}

This study has analysed both spatial and vertical price transmission of global butter export prices and evaluated the impacts of other influencing factors on butter export prices in the global butter export market using a Global Vector Error-Correction Model (GVECM). The empirical research into the long-term price dynamics and market integration as well as interaction of butter export prices with six drivers (CPI for food, exchange rate, fertilizer price, farm-gate milk price, palm oil price, and crude oil price) among major geographically separated exporters (the U.S., the EU, and New Zealand) reveals several significant findings:

(1) Shocks to the butter export price of one country are estimated to be retained within its own country, yet the spill-over effects on other countries' butter export prices are 
weak. The spatial price transmission is incomplete for global butter export prices in geographically separated countries, and butter export markets are not well-integrated.

(2) Negative shocks to crude oil price and palm oil price barely have statistically significant impact on butter export prices. This might be due to its less dependence on crude oil for butter industry and weak substitute effect of palm oil.

(3) Simulated U.S. dollar depreciation against the euro will cause a statistically significant butter export price decreases in the U.S. U.S. dollar depreciation against the aggregated RoW currency and against the New Zealand will not lead to statistically significant butter export price changes.

(4) Shocks to different countries or regions' CPI for food results in different responses on butter export prices. Generally, CPI for food spill over effects and causality relations with butter export prices depends on countries' reliance on butter exports.

(5) Farm-gate milk price has strong price transmission relationship with butter export prices. Price transmission intensity from EU farm-gate milk price is the highest to EU butter export price, next to New Zealand butter export price, and then to U.S. butter export price. Price transmission intensity from New Zealand farm-gate milk price is the highest to New Zealand butter export and next to U.S. butter export price. However, U.S. farm-gate milk price hardly affects global butter export prices, which could be because the U.S. only accounts for a small share of global butter exports. The EU butter export prices are hardly affected by shocks to other countries farm-gate prices, which could be due to its highly active intra-EU trade with high domestic demand and its intervention policies on butter prices.

Global butter export prices are vulnerable to external and internal shocks. Shocks could be easily transmitted from macroeconomic factors, such as CPI of food and exchange rates of one country to butter export markets around the world, and could also be easily transmitted from prices of the upstream raw materials, such as raw milk prices of one country to global butter export prices. Therefore, building the resilience of the food system and global supply chain is necessary not only for the welfare of stakeholders, such as farmers, dairy manufacturing and exporting companies, and consumers, but also for the sustainable development and resilience to shocks of the global dairy market in the era of the COVID-19 pandemic.

\section{Discussion}

The empirical results of this study have several important policy implications for the international butter export markets, especially in the era of the COVID-19 pandemic. Firstly, butter export prices fluctuations in different countries are relatively isolated in its own countries. Although this would keep exports resilient from shocks and fluctuations of butter export prices of other countries, it might cause unfairness in the international trade through arbitrages and beggar-thy-neighbour policy. The global butter export countries should cooperate more closely to enhance market integration for fairer and freer international trade. Secondly, internal shocks, such as fluctuations of food CPI and farm-gate milk price, will affect butter export prices significantly. Fluctuations in farm-gate raw milk price will have strong impacts on export prices of both home country and foreign countries. Price transmission from farm-gate milk prices to butter export prices is significant and has statistically significant spill over effects. Upstream farm-gate price fluctuation could spread both vertically to home butter export price and horizontally to foreign countries' butter export price. Therefore, farm-gate milk price can be regarded as an effective price signal for butter export prices. Policy makers should pay attention to possible factors that fluctuate farm-gate milk prices of both their own country and other major exporters and closely monitor the links between farm-gate milk prices and the butter export market in order to wisely and effectively use policy tools to safeguard the welfare of producers, exporters, and consumers. Thirdly, exchange rate pass-through is incomplete, and butter export prices are unproportionally affected and display different patterns for different country currency changes. Closely monitoring exchange rate fluctuations to make precautions will facilitate 
the policy makers to design and implement wise tools to stabilize the butter export market and prices. Fourthly, although crude oil prices and palm oil prices are examined to have no statistically significant impacts on butter export prices, it is still necessary for policy makers of the dairy industry to pay attention to extreme fluctuations of these prices, especially when its reliance on crude oil increases or major importers' willingness to consume substitute product increases. Finally, it is necessary for dairy industry to adopt more sustainable practices to achieve resilience with increased profitability and sustainability of the industry and a sustainable ecosystem, such as implementation of leagile practices [57].

This study contributes to the literature as follows: first, it addresses a gap in spatial price transmission research that focuses on the prices without considering other influencing factors. Second, studying the transmission effects on butter export prices, the crude oil, and other macroeconomic factors fits with current research trends towards potential links between energy, agriculture commodities, and macroeconomic uncertainties. Third, this study expands the application of the GVAR model to the dairy sector for the first time and validates its effectiveness in analysing spatial price dynamics with various factors across geographically separated countries (region). Besides, this study on the macroeconomic impact on dairy industry in light of a more market-oriented EU dairy policy and rising global economic uncertainties might also provide policy makers with a basis for the development of timely butter export strategy adjustments and policy-making processes. Finally, panel data approaches provide more useful information by deriving information from both time and cross-country dimensions rather than simple time-series methods and could link the spatial price transmission with the vertical price transmission in an effective way, which expands the spatial price transmission scope for export-oriented products, thereafter providing dairy producers and exporters with more useful information on price mechanisms to stabilize butter export prices.

There are several potential directions for future research. Firstly, grain commodity prices used as feeds (e.g., corn price), inputs in the dairy sector (e.g., labour prices, regulations, capital investment), and climate indicators (e.g., rainfall precipitation, temperature, and extreme weather events; see [58,59] for analysis of climate changes impacts on crop commodities) may be incorporated into the analysis to discuss impacts across sectors and climate-change effects. Second, the price transmission among various dairy commodities, such as milk powders, cheese, and whey, and their interlinkage with macroeconomic factors. Third, innovative models, such as the regime-switching GVAR and copula-GARCH model, may be used to compare price transmission and dynamics under different regimes. Fourth, further interdisciplinary studies with international trade law can be conducted to address reforms directions for current WTO framework and regional trade to better deal with global market failure, market integration, and global economic integration, thus strengthening the resilience and sustainability of international trade.

Author Contributions: Conceptualization, H.X., C.L., and L.W.; methodology, H.X.; software, H.X.; validation, H.X.; formal analysis, H.X.; investigation, H.X.; resources, H.X.; data curation, H.X.; writing-original draft preparation, H.X.; writing-review and editing, H.X., C.L., L.W., and W.-H.S.; visualization, H.X.; supervision, C.L. and L.W.; project administration, C.L. and L.W.; funding acquisition, H.X. and L.W. All authors have read and agreed to the published version of the manuscript.

Funding: This research received no external funding.

Institutional Review Board Statement: Not applicable.

Informed Consent Statement: Not applicable.

Conflicts of Interest: The authors declare no conflict of interest. 


\section{Appendix A}

Table A1. Data description: domestic and global data series.

\begin{tabular}{|c|c|c|c|c|}
\hline $\begin{array}{l}\text { Categories of } \\
\text { Variables }\end{array}$ & Variables & Description & Source & URL \\
\hline \multirow[t]{2}{*}{ Global Variables } & Crude oil price, $p_{i t}^{c o}$ & $\begin{array}{l}\text { Average spot price of } \\
\text { Brent, Dubai, and West } \\
\text { Texas Intermediate, } \\
\text { equally weighed; Nominal } \\
\text { U.S. dollar per barrel }\end{array}$ & \multirow{2}{*}{$\begin{array}{l}\text { The World Bank } \\
\text { Commodity Markets } \\
\text { "pink sheet" data } \\
\text { commodity prices }\end{array}$} & \multirow{2}{*}{$\begin{array}{l}\text { https:/ / www.worldbank. } \\
\text { org/en/research/ } \\
\text { commodity-markets, } \\
\text { accessed on } 01 \text { May } 2020\end{array}$} \\
\hline & Palm oil price, $p_{i t}^{p o}$ & $\begin{array}{l}\text { Nominal U.S. dollar per } \\
\text { metric ton (MT) }\end{array}$ & & \\
\hline \multirow{12}{*}{ Domestic variables } & \multirow{3}{*}{$\begin{array}{l}\text { Butter export prices (butter in } \\
\text { the trade market studied in } \\
\text { this chapter is categorised } \\
\text { according to Harmo-nized } \\
\text { System Chapter } 4 \text { (HS-4): } \\
\text { 0405-Butter and other fats and } \\
\text { oils derived from milk; dairy } \\
\text { spreads), } p_{i t}^{e}\end{array}$} & United States & $\begin{array}{l}\text { USDA Foreign } \\
\text { Agricultural } \\
\text { Services-GATS database }\end{array}$ & $\begin{array}{l}\text { https://apps.fas.usda. } \\
\text { gov/gats/default.aspx, } \\
\text { accessed on } 01 \text { May } 2020\end{array}$ \\
\hline & & European Union-28 & Eurostat database & $\begin{array}{l}\text { https://ec.europa.eu/ } \\
\text { eurostat/data/database, } \\
\text { accessed on } 01 \text { May } 2020\end{array}$ \\
\hline & & New Zealand & UN Comtrade database & $\begin{array}{l}\text { https:// comtrade.un.org/ } \\
\text { data/, accessed on } \\
01 \text { May } 2020\end{array}$ \\
\hline & $\begin{array}{l}\text { bilateral exchange rate (rest of } \\
\text { World: Weighted average of } \\
\text { China: Chinese yuan; Japan: } \\
\text { Japanese yen; Russian } \\
\text { Federation: Russian ruble; } \\
\text { Ukraine: Ukrainian Hryvnia. } \\
\text { Weight are given by the dairy } \\
\text { export quantity of each } \\
\text { country to the total dairy } \\
\text { export quantity of these } \\
\text { studied countries.), } e_{i t}\end{array}$ & $\begin{array}{l}\text { Nominal exchange rate: } \\
\text { Local currency per unit of } \\
\text { US dollar }\end{array}$ & FRED Economic Data & $\begin{array}{l}\text { NZ: https: / / fred. } \\
\text { stlouisfed.org/series / } \\
\text { CCUSMA02NZM618N, } \\
\text { accessed on 01 May 2020 } \\
\text { EU: https: / fred. } \\
\text { stlouisfed.org/series/ } \\
\text { CCUSMA02EZM618N, } \\
\text { accessed on 01 May 2020 }\end{array}$ \\
\hline & Fertilizer price index, $p_{i t}^{f}$ & $\begin{array}{l}\text { Fertilizers index includes } \\
\text { natural phosphate rock, } \\
\text { phosphate, potassium, } \\
\text { and nitrogenous products. }\end{array}$ & $\begin{array}{l}\text { The World Bank } \\
\text { Commodity Markets } \\
\text { "pink sheet" data } \\
\text { commodity prices }\end{array}$ & $\begin{array}{l}\text { https://www.worldbank. } \\
\text { org/en/research/ } \\
\text { commodity-markets, } \\
\text { accessed on } 01 \text { May } 2020\end{array}$ \\
\hline & \multirow{4}{*}{$\begin{array}{l}\text { Consumer food price index, } \\
C P I_{i t}\end{array}$} & United States & OECD database & $\begin{array}{l}\text { https://stats.oecd.org/, } \\
\text { accessed on } 01 \text { May } 2020\end{array}$ \\
\hline & & European Union-28 & Eurostat database-HICP & $\begin{array}{l}\text { https://ec.europa.eu/ } \\
\text { eurostat/data/database, } \\
\text { accessed on } 01 \text { May } 2020\end{array}$ \\
\hline & & New Zealand & $\begin{array}{l}\text { Stats } \\
\text { NZ-infoshar-Economic } \\
\text { Indicator-Consumers Price } \\
\text { Index }\end{array}$ & $\begin{array}{l}\text { http://archive.stats.govt. } \\
\text { nz/infoshare/, } \\
\text { accessed on } 01 \text { May } 2020\end{array}$ \\
\hline & & Rest of World & OECD database & $\begin{array}{l}\text { https://stats.oecd.org/, } \\
\text { accessed on } 01 \text { May } 2020\end{array}$ \\
\hline & \multirow{3}{*}{ Farm-gate raw milk prices, $p_{i t}^{m}$} & United States & CLAL.it & $\begin{array}{l}\text { https: } \\
\text { // www.clal.it/en/index. } \\
\text { php?section=latte_usa, } \\
\text { accessed on } 01 \text { May } 2020\end{array}$ \\
\hline & & European Union-28 & $\begin{array}{l}\text { Milk market observatory, } \\
\text { European Commission }\end{array}$ & $\begin{array}{l}\text { https://ec.europa.eu/ } \\
\text { info/food-farming- } \\
\text { fisheries/farming/facts- } \\
\text { and-figures/markets/ } \\
\text { overviews/market- } \\
\text { observatories/milk_en, } \\
\text { accessed on 01 May 2020 }\end{array}$ \\
\hline & & New Zealand & CLAL.it & $\begin{array}{l}\text { https://www.clal.it/en/ } \\
\text { index.php?section=latte__ } \\
\text { new_zealand, accessed on } \\
01 \text { May } 2020\end{array}$ \\
\hline
\end{tabular}


Table A2. Descriptive Statistics of Domestic Variables.

\begin{tabular}{|c|c|c|c|c|c|}
\hline & Mean & Median & Maximum & Minimum & Std. Dev. \\
\hline \multicolumn{6}{|c|}{ Butter Export Prices } \\
\hline The U.S. & 4.70 & 4.70 & 4.94 & 4.44 & 0.11 \\
\hline EU-28 & 4.84 & 4.83 & 5.15 & 4.47 & 0.17 \\
\hline New Zealand & 4.87 & 4.88 & 5.29 & 4.47 & 0.23 \\
\hline \multicolumn{6}{|l|}{ Rest of World } \\
\hline \multicolumn{6}{|l|}{ Exchange Rate } \\
\hline \multicolumn{6}{|l|}{ The U.S. } \\
\hline EU-28 & 4.51 & 4.50 & 4.66 & 4.34 & 0.09 \\
\hline New Zealand & 4.55 & 4.56 & 4.70 & 4.39 & 0.09 \\
\hline Rest of World & 4.35 & 4.51 & 4.75 & 3.96 & 0.27 \\
\hline \multicolumn{6}{|l|}{ Fertilizer Price } \\
\hline The U.S. & 4.60 & 4.60 & 5.09 & 4.24 & 0.23 \\
\hline EU-28 & 4.50 & 4.46 & 4.93 & 4.21 & 0.17 \\
\hline New Zealand & 4.54 & 4.53 & 4.97 & 4.19 & 0.18 \\
\hline Rest of World & 4.35 & 4.35 & 4.68 & 3.98 & 0.16 \\
\hline \multicolumn{6}{|c|}{ Consumer Price } \\
\hline The U.S. & 4.57 & 4.59 & 4.61 & 4.49 & 0.04 \\
\hline EU-28 & 4.60 & 4.61 & 4.68 & 4.51 & 0.04 \\
\hline New Zealand & 4.60 & 4.60 & 4.66 & 4.51 & 0.03 \\
\hline Rest of World & 4.52 & 4.52 & 4.81 & 4.21 & 0.19 \\
\hline \multicolumn{6}{|c|}{ Farm Gate Milk Price } \\
\hline The U.S. & 4.67 & 4.64 & 5.01 & 4.44 & 0.13 \\
\hline EU-28 & 4.69 & 4.69 & 4.88 & 4.43 & 0.10 \\
\hline New Zealand & 4.87 & 4.89 & 5.18 & 4.47 & 0.17 \\
\hline Rest of World & & & & & \\
\hline
\end{tabular}

\section{References}

1. Gozgor, G. Effects of the agricultural commodity and the food price volatility on economic integration: An empirical assessment. Empir. Econ. 2019, 56, 173-202. [CrossRef]

2. Steinberg, J.B. Brexit and the macroeconomic impact of trade policy uncertainty. J. Int. Econ. 2019, 117, 175-195. [CrossRef]

3. Tam, P.S. Global trade flows and economic policy uncertainty. Appl. Econ. 2018, 50, 3718-3734. [CrossRef]

4. Fousekis, P.; Emmanouilides, C.; Grigoriadis, V. Price linkages in the international skim milk powder market: Empirical evidence from nonparametric and time-varying copulas. Aust. J. Agric. Resour. Econ. 2017, 61, 135-153. [CrossRef]

5. Fousekis, P.; Trachanas, E. Price transmission in the international skim milk powder markets. Appl. Econ. 2016, 48, 5233-5245. [CrossRef]

6. Wang, Q.; Liu, C.-Q.; Zhao, Y.-F.; Kitsos, A.; Cannella, M.; Wang, S.-K.; Han, L. Impacts of the COVID-19 pandemic on the dairy industry: Lessons from China and the United States and policy implications. J. Integr. Agric. 2020, 19, 2903-2915. [CrossRef]

7. Sands, R.; Westcott, P.; Price, J.M.; Beckman, J.; Leibtag, E.; Lucier, G.; McBride, W.D.; McGranahan, D.; Morehart, M.; Roeger, E. Impacts of Higher Energy Prices on Agriculture and Rural Economies; Economic Research Service, USDA: Washington, DC, USA, 2011.

8. Sato, M.; Dechezleprêtre, A. Asymmetric industrial energy prices and international trade. Energy Econ. 2015, 52, S130-S141. [CrossRef]

9. Taghizadeh-Hesary, F.; Rasoulinezhad, E.; Yoshino, N. Energy and food security: Linkages through price volatility. Energy Policy 2019, 128, 796-806. [CrossRef]

10. Zilberman, D.; Sproul, T.; Rajagopal, D.; Sexton, S.; Hellegers, P. Rising energy prices and the economics of water in agriculture. Water Policy 2008, 10, 11-21. [CrossRef]

11. Felbermayr, G.; Kinzius, L.; Yalcin, E. Hidden Protectionism: Non-Tariff Barriers and Implications for International Trade; IFO Forschungsberichte: Munich, Germany, 2017.

12. Pesaran, M.H.; Schuermann, T.; Weiner, S.M. Modeling regional interdependencies using a global error-correcting macroeconometric model. J. Bus. Econ. Stat. 2004, 22, 129-162. [CrossRef]

13. Chudik, A.; Pesaran, M.H. Theory and practice of GVAR modelling. J. Econ. Surv. 2016, 30, 165-197. [CrossRef]

14. The OECD-FAO Agricultural Outlook. OECD-FAO Agricultural Outlook 2013; The OECD-FAO Agricultural Outlook; OECD Publishing: Paris, France; FAO: Rome, Italy, 2013. 
15. The OECD-FAO Agricultural Outlook. OECD-FAO Agricultural Outlook 2014; The OECD-FAO Agricultural Outlook; OECD Publishing: Paris, France; FAO: Rome, Italy, 2014.

16. The OECD-FAO Agricultural Outlook. OECD-FAO Agricultural Outlook 2015; The OECD-FAO Agricultural Outlook; OECD Publishing: Paris, France; FAO: Rome, Italy, 2015.

17. The OECD-FAO Agricultural Outlook. OECD-FAO Agricultural Outlook 2017-2026; The OECD-FAO Agricultural Outlook; OECD Publishing: Paris, France; FAO: Rome, Italy, 2017.

18. The OECD-FAO Agricultural Outlook. OECD-FAO Agricultural Outlook 2018-2027; The OECD-FAO Agricultural Outlook; OECD Publishing: Paris, France; FAO: Rome, Italy, 2018.

19. Fousekis, P.; Grigoriadis, V. Price co-movement in the principal skim milk powder producing regions: A wavelet analysis. Econ. Bull. 2016, 36, 477-492.

20. Huchet-Bourdon, M. Agricultural Commodity Price Volatility: An Overview; OECD Food, Agriculture and Fisheries Working Papers, no. 52; OECD Publishing: Paris, France, 2011.

21. Bergmann, D.; O'Connor, D.; Thümmel, A. An analysis of price and volatility transmission in butter, palm oil and crude oil markets. Agric. Food Econ. 2016, 4, 23. [CrossRef]

22. Serra, T.; Zilberman, D. Biofuel-related price transmission literature: A review. Energy Econ. 2013, 37, 141-151. [CrossRef]

23. The OECD-FAO Agricultural Outlook. OECD-FAO Agricultural Outlook 2011; The OECD-FAO Agricultural Outlook; OECD Publishing: Paris, France; FAO: Rome, Italy, 2011.

24. O'Connor, D.; Keane, M.; Barnes, E. Measuring Volatility in Dairy Commodity Prices. In Proceedings of the 113th Seminar European Association of Agricultural Economists, Chania, Crete, Greece, 3-6 September 2009.

25. Abbott, P.C.; Hurt, C.; Tyner, W.E. What's Driving Food Prices? (Issue Report: No. 741-2016-51225); Farm Foundation: Oak Brook, IL, USA, 2008.

26. Piesse, J.; Thirtle, C. Three bubbles and a panic: An explanatory review of recent food commodity price events. Food Policy 2009, 34, 119-129. [CrossRef]

27. Kravis, I.B.; Lipsey, R.E. Export prices and the transmission of inflation. Am. Econ. Rev. 1977, 67, $155-163$.

28. Galesi, A.; Lombardi, M.J. External shocks and international inflation linkages. In The GVAR Handbook: Structure and Applications of a Macro Model of the Global Economy for Policy Analysis; OUP Oxford: Oxford, UK, 2013; p. 70.

29. Bettendorf, T. Investigating Global Imbalances: Empirical evidence from a GVAR approach. Econ. Model. 2017, 64, 201-210. [CrossRef]

30. Bussiere, M.; Chudik, A.; Mehl, A. How have global shocks impacted the real effective exchange rates of individual euro area countries since the euro's creation? BE J. Macroecon. 2013, 13, 1-48. [CrossRef]

31. Camarero, M.; Carrion-i-Silvestre, J.L.; Tamarit, C. External imbalances from a GVAR perspective. World Econ. 2021. [CrossRef]

32. Kim, H. International Spillovers of Shocks and Economic Relationships: A Structural GVAR Approach; University of Colorado: Boulder, CO, USA, 2021.

33. Favero, C.; Giavazzi, F.; Perego, J. Country Heterogeneity and the International Evidence on the Effects of Fiscal Policy. IMF Econ. Rev. 2011, 59, 652-682. [CrossRef]

34. Feldkircher, M.; Huber, F. The International Transmission of US Structural Shocks-Evidence from Global Vector Autoregressions. Eur. Econ. Rev. 2016, 81, 167-188. [CrossRef]

35. Georgiadis, G. Determinants of global spillovers from US monetary policy. J. Int. Money Financ. 2016, 67, 41-61. [CrossRef]

36. Georgiadis, G. Examining asymmetries in the transmission of monetary policy in the euro area: Evidence from a mixed cross-section global VAR model. Eur. Econ. Rev. 2015, 75, 195-215. [CrossRef]

37. Hebous, S.; Zimmermann, T. Estimating the effects of coordinated fiscal actions in the euro area. Eur. Econ. Rev. 2013, 58, 110-121. [CrossRef]

38. Ebrahimi, N.; Pedram, M.; Mousavi, M.H. The Effect of Fiscal Policy on Unemployment and Inflation in Provinces of Iran: A GVAR Approach. Econ. Modeling 2021. [CrossRef]

39. Colabella, A. Do ECB's Monetary Policies Benefit EMEs? A GVAR Analysis on the Global Financial and Sovereign Debt Crises and Postcrises Period. Oxf. Bull. Stat. 2021, 83, 472-494. [CrossRef]

40. Eickmeier, S.; Ng, T. How do US credit supply shocks propagate internationally? A GVAR approach. Eur. Econ. Rev. 2015, 74, 128-145. [CrossRef]

41. Konstantakis, K.N.; Michaelides, P.G. Transmission of the debt crisis: From EU15 to USA or vice versa? A GVAR approach. J. Econ. Bus. 2014, 76, 115-132. [CrossRef]

42. Xu, T. The Role of Credit in International Business Cycles; Staff Working Paper 2012-36; Bank of Canada: Ottawa, ON, Canada, 2012.

43. Hiebert, P.; Vansteenkiste, I. International trade, technological shocks and spillovers in the labour market: A GVAR analysis of the US manufacturing sector. Appl. Econ. 2010, 42, 3045-3066. [CrossRef]

44. Gupta, R.; Demirer, R. The Financial US Uncertainty Spillover Multiplier: Evidence from a GVAR Model; Working Papers 202145; University of Pretoria: Pretoria, South Africa, 2021.

45. Khalilnezhad, Z.; Eslamloueyan, K.; Hadian, E.; Dehghan, Z. The Effect of Falling Oil Prices on Major Oil Exporting Countries through Trade and Financial Channels: A GVAR Model. Q. Energy Econ. Rev. 2020, 16, 1-29.

46. Abbas, S.; Nguyen, V.C.; Yanfu, Z.; Nguyen, H.T. The Impact of China Exchange Rate Policy on its Trading Partners: Evidence Based on the GVAR Model. J. Asian Financ. Econ. Bus. 2020, 7, 131-141. [CrossRef] 
47. Gunter, U.; Zekan, B. Forecasting air passenger numbers with a GVAR model. Ann. Tour. Res. 2021, 89, 103252. [CrossRef]

48. Youcai, Y.; Lulu, G.; Qianzi, S. Spillover Effects of Technological Innovation Efficiency among High-tech Industries in ChinaBased on GVAR Model. Manag. Rev. 2020, 32, 138-149.

49. Konstantakis, K.N.; Michaelides, P.G.; Papageorgiou, T.; Daglis, T. Modelling sectoral spillovers in the USA (1992-2015): A GVAR approach. J. Econ. Stud. 2020, 47, 561-595. [CrossRef]

50. Gutierrez, L.; Piras, F.; Roggero, P.P. A global vector autoregression model for the analysis of wheat export prices. Am. J. Agric. Econ. 2015, 97, 1494-1511. [CrossRef]

51. Pierre, G.; Kaminski, J. Cross country maize market linkages in Africa: Integration and price transmission across local and global markets. Agric. Econ. 2019, 50, 79-90. [CrossRef]

52. Gruss, B. After the Boom-Commodity Prices and Economic Growth in Latin America and the Caribbean; International Monetary Fund: Washington, DC, USA, 2014.

53. Smith, L.; Galesi, A. GVAR Toolbox 2.0; Judge Business School, University of Cambridge: Cambridge, UK, 2014.

54. Harbo, I.; Johansen, S.; Nielsen, B.; Rahbek, A. Asymptotic inference on cointegrating rank in partial systems. J. Bus. Econ. Stat. 1998, 16, 388-399.

55. Dees, S.; Di Mauro, F.; Pesaran, M.H.; Smith, L.V. Exploring the international linkages of the euro area: A global VAR analysis. J. Appl. Econom. 2007, 22, 1-38. [CrossRef]

56. Fackler, P.L.; Goodwin, B.K. Spatial price analysis. Handb. Agric. Econ. 2001, 1, 971-1024.

57. Mathiyazhagan, K.; Agarwal, V.; Appolloni, A.; Saikouk, T.; Gnanavelbabu, A. Integrating lean and agile practices for achieving global sustainability goals in Indian manufacturing industries. Technol. Forecast. Soc. Chang. 2021, 171, 120982. [CrossRef]

58. Chatzopoulos, T.; Domínguez, I.P.; Zampieri, M.; Toreti, A. Climate extremes and agricultural commodity markets: A global economic analysis of regionally simulated events. Weather. Clim. Extrem. 2020, 27, 100193. [CrossRef]

59. Gornall, J.; Betts, R.; Burke, E.; Clark, R.; Camp, J.; Willett, K.; Wiltshire, A. Implications of climate change for agricultural productivity in the early twenty-first century. Philos. Trans. R. Soc. B Biol. Sci. 2010, 365, 2973-2989. [CrossRef] [PubMed] 